Asy Syar'iyyah: Jurnal Ilmu Syari'ah dan Perbankan Islam - ISSN 2089-7227 (p) 2598-8522 (e)

Vol. 4, No. 1, Juni 2019, pp. 68 - 94

\title{
INVESTASI TABUNGAN DI BANK SYARIAH DALAM PRESPEKTIF HUKUM EKONOMI SYARIAH
}

\author{
Feby Ayu Amalia \\ IAIN Syaikh Abdurrahman Siddik Bangka Belitung
}

Email: febyayuamalia@gmail.com

\begin{abstract}
Investment is a commitment to the activities undertaken by a person or legal entity, to set aside a portion of his income in order to be used to conduct a business with the hope at a certain time will get the results (profit). The rise of investment fraud, and the lack of clarity on the returns to profits derived from the investment returns halal or not, require the public to be more selective in investing their wealth. This article discusses the concept of investment and savings investment in Sharia Bank with the sharia economic law perspective. Islamic banking undertakes the business of fund raising, based on Sharia Principles. One of Sharia Bank's investment products is a savings whose investment is based on wadi'ah contract and investment fund based on mudharabah contract or other contract which is not contrary to sharia principles. The regulation of savings in a Sharia Bank is regulated by Law No. 21 of 2008, and Fatwa DSN No: 02 / DSN-MUI / IV / 2000. The law of investing in Sharia Banks is permissible, because by investing in Sharia Banks slowly we can help the equity of economy and economic welfare.
\end{abstract}

Keywords: Investment, Wadi'ah Savings, and Mudharabah Savings

\begin{abstract}
Abstrak
Investasi adalah komitmen atas kegiatan yang dilakukan oleh seseorang atau badan hukum, untuk menyisihkan sebagian pendapatannya agar dapat digunakan untuk melakukan suatu usaha dengan harapan pada suatu waktu tertentu akan mendapatkan hasil (keuntungan).Maraknya penipuan investasi, dan ketidakjelasan hasil keuntungan yang didapat apakah diperoleh dari hasil keuntungan investasi yang halal atau tidaknya, mengharuskan masyarakat untuk lebih selektifdalam menginvestasikan hartanya. Artikel ini mendiskusikan konsep investasi dan investasi tabungan di Bank Syariah dengan prespektif hukum ekonomi syariah. Perbankan syariah melakukan kegiatan usaha penghimpunan dana, berdasarkan PrinsipSyariah. Salah satu
\end{abstract}


produk investasi Bank Syariah adalah Tabungan yang investasinya berdasarkan akad wadi'ah dan investasi dana berdasarkan akad mudharabah atau akad lain yang tidak bertentangan dengan prinsip syariah.Regulasi tabungan di Bank Syariah diatur oleh Undang-undang No. 21 Tahun 2008, dan Fatwa DSN No:02/DSN-MUI/IV/2000. Hukum dari berinvestasi di Bank Syariah adalah boleh, karena dengan berinvestasi di Bank Syariah secara perlahan kita dapat membantu pemerataan ekonomi dan kesejahteraan ekonomi.

Kata kunci : Investasi, Tabungan Wadi'ah, dan Tabungan Mudharabah

\section{A. Pendahuluan}

Bank Syari'ah merupakan lembaga intermediasi dan penyedia jasa keuangan yang bekerja berdasarkan etika dan sistem Islam. Khususnya yang etika dan sistem Islam mengarahkan lembaga ini bebas dari bunga (riba), bebas dari kegiatan spekulatif dan perjudian (maysir), bebas dari hal-hal yang tidak jelas (gharar). (dengan demikian lembaga ini berjalan dengan) berprinsip keadilan, dan hanya membiayai kegiatan usaha yang halal yang kesemuanya merupakan prinsip-prinsip perbankan syari'ah.

Dalam fungsinya Bank syariah sebagai lembaga intermediasi yaitu sebagai perantara pihak-pihak yang memiliki kelebihan dana (surplus unit), dengan pihakpihak yang mengalami kekurangan dana (deficit unit), maka bank harus melakukan kegiatan penghimpunan dana dari pihak surplus unit yang nantinya akan disalurkan kepada deficit unit. ${ }^{1}$ Tujuan dari kegiatan investasi penghimpun dana ini adalah untuk memperbesar modal, memperbesar aset dan memperbesar kegiatan pembiayaan sehingga nantinya dapat mendukung bank sebagai lembaga intermediasi. Undang-undang No. 21 tahun 2008 tentang Perbankan Syariah Pasal 1 angka 24 mengartikan Investasiadalah dana yang dipercayakan oleh nasabah kepada bank syariah dan/atau UUS berdasarkan akad mudharabah atau akad lainnya yang tidak bertentangan dengan Prinsip

${ }^{1}$ Heri Sudarsono, Bank dan lembaga Keuangan Syariah Deskripsi dan Ilustrasi, (Yogyakarta: Ekonisia, 2003), hlm. 63 
Syariah dalam bentuk Deposito, Tabungan, atau bentuk lainnya yang dipersamakan dengan itu. ${ }^{2}$

Dengan adanya produk investasi di Bank Syariah tentunya dapat menjadi salah satu solusi bagi para surplus unit yang ingin menginvestasikan hartanya secara aman. Karena Bank Syariah tentunya akan mengelola dana dan menyalurkan dana yang didapatkan melalui pembiayaan ke usaha-usaha yang sesuai prinsip syariah, sesuai dengan SK Dir BI No. 32/34/KEP/DIR tentang kegiatan dan larangan usaha Bank Syariah. Dan dengan menabung di Bank Syariah secara perlahan dapat membantu dalam kesejahteraan dan pemerataan perekonomian bangsa.

Dari pembahasan di atas penulis akan membahas tentang investasi tabungan di bank syariah dalam prespektif hukum ekonomi syariah

\section{B. Pembahasan}

\section{Investasi Dan Tujuan Investasi}

Istilah investasi berasal dari bahasa Latin, yaitu investire (memakai), sedangkan dalam bahasa Inggris disebut dengan investment yang memiliki arti menanam. Dalam Kamus Lengkap Ekonomi, investasi didefinisikan sebagai penukaran uang dengan bentuk-bentuk kekayaan lain seperti saham atau harta yang tidak bergerak yang diharapkan dapat ditahan selama periode waktu tertentu supaya menghasilkan pendapatan. ${ }^{3}$

Investasi atau penanaman modal berdasarkan Undang-undang No. 25 tahun 2007 tentang penanaman modal adalah segala bentuk kegiatan menanam modal, baik oleh penanam modal dalam negeri

${ }^{2}$ UU No. 21 Tahun 2008 Tentang Perbankan Syariah

${ }^{3}$ Nurul Huda dan Mustafa Edwin Nasution, Investasi pada Pasar Modal Syariah, (Jakarta: Kencana, 2008), hlm. 7. 
Investasi Tabungan di Bank Syariah dalam Perspektif Hukum Ekonomi Syariah

maupun penanam modal asing untuk melakukan usaha di wilayah Republik Indonesia. ${ }^{4}$

Para ahli dalam bidang investasi memiliki pandangan yang berbeda mengenai konsep teoritis tentang investasi. Fitzgeral, mengartikan investasi adalah aktivitas yang berkaitan dengan usaha penarikan sumber-sumber (dana) yang dipakai untuk mengadakan barang modal pada saat sekarang, dan dengan barang modal akan dihasilkan aliran produk baru di masa yang akan datang. Definisi lain, Kamaruddin Ahmad mengemukakan bahwa yang dimaksud dengan investasi adalah menempatkan uang atau dana dengan harapan untuk memperoleh tambahan atau keuntungan tertentu atas uang atau dana tersebut. ${ }^{5}$

Dari pengertian investasi diatas, dapat disimpulkan bahwa investasi adalah komitmen atas kegiatan yang dilakukaan oleh seseorang atau badan hukum, untuk menyisihkan sebagian pendapatannya agar dapat digunakan untuk melakukan suatu usaha dengan harapan pada suatu waktu tertentu akan mendapatkan hasil (keuntungan).

Pada umumnya investasi dibedakan menjadi, yaitu investasi financial asset dan pada real asset. Investasi pada financial asset dilakukan di pasar uang, misalnya berupa tabungan, deposito, saham, obligasi, dan lainnya. Sedangkan inventasi pada real asset dapat dilakukan dengan pembelian aset produktif, seperti investasi dibidang properti.

Sedangkan tujuan dari melakukan investasi adalah mendapatkan keuntungan, ada beberapa alasan mengapa seseorang melakukan investasi, antara lain adalah:

${ }^{4}$ Undang-undang No. 25 Tahun 2007 Tentang Penanaman Modal

${ }^{5}$ Abdul Manan,Hukum Ekonomi Syariah:Dalam Prespektif Kewenangan Peradilan Agama, (Jakarta: Kencana, 2012), hlm. 149 
1. Untuk mendapatkan kehidupan yang lebih layak di masa yang akan datang.

2. Mengurangi tekanan inflasi.

3. Dorongan untuk menghemat pajak 6

\section{Investasi Dalam Prespektif Syariah}

Islam memandang semua perbuatan manusia dalam kehidupan sehari-harinya, termasuk aktivitas ekonominya sebagai investasi yang akan mendapatkan hasil. Investasi yang melanggar syariah akan mendapatkan balasan yang setimpal, begitu pula investasi yang sesuai dengan syaria. Hasil investasi dalam Islam sesuai dengan besarnya sumber daya yang diinvestasikannya di dunia bisa berlipat-lipat ganda. Allah berfirman:

"Sesuatu yang bernyawa tidak akan mati melainkan dengan izin Allah, sebagai ketetapan yang telah ditentukan waktunya. barang siapa menghendaki pahala dunia, niscaya Kami berikan kepadanya pahala dunia itu, dan barang siapa menghendaki pahala akhirat, Kami berikan (pula) kepadanya pahala akhirat itu. dan Kami akan memberi Balasan kepada orang-orang yang bersyukur."

Jadi, investasi syariah adalah pengorbanan sumber daya pada masa sekarang untuk mendapatkan hasil yang pasti, dengan memperoleh hasil yang lebih besar di masa yang akan datang, baik langsung maupun tidak langsung dengan tetap berpijak pada prinsipprinsip syariah. Selain itu, semua bentuk investasi dilakukan dalam rangka ibadah kepada Allah untuk mencapai kebahagiaan. ${ }^{7}$

${ }^{6}$ Kamaruddin Ahmad, Dasar-Dasar Manajemen Investasi Dan Portofolio,(Jakarta : Rineka Cipta, 2004), hlm. 3-4

${ }^{7}$ Muhammad Nafik HR, Bursa Efek dan Investasi Syariah, (Jakarta:Serambi, 2009), hlm.70. 
Investasi Tabungan di Bank Syariah dalam Perspektif Hukum Ekonomi Syariah

Investasi syariah adalah bertujuan untuk tercapainya maqasid syariah, yaitu untuk memelihara agama, memelihara jiwa, memelihara akal, memelihara keturunan, dan memelihara harta.

\section{Prinsip Investasi Berdasarkan Syariah ${ }^{8}$}

1. Prinsip Halal

M. Nadratuzzaman Husen dkk. Mengemukakan bahwa berinvestasi itu harus dengan cara yang halal karena:

a. Kehendak Syar'i

b. Halal terdapat keberkahan

c. Halal mengandung manfaat dan mashlahah

d. Halal membawa pengaruh positif bagi prilaku manusia

2. Prinsip Mashlahah

Investasi yang dianjurkan untuk dilakukan adalah investasi yang dapat memberikan dampak sosial lingkungan yang positif bagi kehidupan masyarakat, baik untuk generasi saat ini maupun yang akan datang.

3. Prinsip Terhindar dari Investasi yang Terlarang

a. Investasi yang syubhat

b. Investasi yang haram

1) Haram karena tadlis

2) Haram karena gharar

3) Haram karena maysir

4) Haram karena riba

c. Investasi yang mengandung unsur ihtikar dan an-najasy

\footnotetext{
${ }^{8}$ Abdul Manan,Hukum Ekonomi,,,hlm. 181-196
} 


\section{Tabungan}

Dengan mendasarkan pengertian Bank menurut Undang-undang No. 10 Tahun 1998 tentang perubahan Undang-undang No. 7 Tahun 1992 tentang perbankan dan Undang-undang No. 21 Tahun 2008 tentang Perbankan Syariah tampak bahwaperan Bank sebagai salah satu lembaga keuangan memiliki fungsi menghimpun dana masyarakat. Pada pasal 3 PBI No. 9/19/PBI/2007 menegaskan bahwa dalam kegiatan penghimpun dana Bank Syariah hanya menggunakan akad wadiah dan mudharabah. Dana yang telah terhimpun, kemudian disalurkan kembali kepada masyarakat. Jika dilihat dari fungsi bank syari'ah mengumpulkan dana dan menyalurkan dana kembali kepada masyarakat, maka bank syariah berfungsi sebagai perantara keuangan (financial intermediary) antara pihak yang mengalami kelebihan dana (surplus units) kepada pihak yang mengalami kekurangan modal (deficit units). ${ }^{9}$

Pada perbankan konvensional penghimpunan dana dari masyarakat dilakukan dalam bentuk tabungan (saving deposit), deposito (time deposit), giro (demand deposit). Hampir sama dengan perbankan Bank syariah menerapkan dua akad dalam tabungan, yaitu wadi'ah dan mudharabah. Tabungan yang menerapkan akad wadi'ah mengikuti prinsip-prinsip wadi'ah yad adh-dhamanah, artinya tabungan ini tidak mendapatkan keuntungan karena ia titipan dan dapat diambil sewaktuwaktu dengan menggunakan buku tabungan atau media lain seperti ATM. Tabungan yang berdasarkan akad wadi'ah ini tidak mendapatkan keuntungan dari bank karena bersifat titipan. Akan tetapi bank tidak dilarang jika ingin memberikan semacam bonus / hadiah. ${ }^{10}$

${ }^{9}$ Muhammad,Manajemen Bank Syariah,(Yogyakarta: UPP AMP YKPN,2005) hlm.261

${ }^{10}$ Muhammad Syafi' I Antonio,Bank Syariah Dari Teori ke Praktik, (Jakarta: Gema Insani,2001) hlm. 156 
Investasi Tabungan di Bank Syariah dalam Perspektif Hukum Ekonomi Syariah

Tabungan yang menerapkan akad mudharabah mengikuti prinsipprinsip akad mudharabah. Di antaranya, yaitu pertama, keuntungan dari dana yang digunakan harus dibagi antara shahibul maal dan mudharib. Kedua, adanya tenggang waktu antara dana yang diberikan dan pembagian keuntungan, karena untuk melakukan investasi dengan memutarkan dana itu diperlukan waktu yang cukup. ${ }^{11}$

Perbedaan menabung di Bank Syariah dan bank konvensional, yaitu: pertama,terletak pada akad. Pada Bank Syariah semua transaksi harus berdasarkan akad yang dibenarkan oleh syariah. Sedangkan pada bank konvensional, transaksi pembukuan rekening, baik giro, tabungan, maupun deposito, berdasarkan perjanjian titipan, namun perjanjian titipan ini tidak mengikuti prinsip manapun dalam muamalah syariah. Kedua terletak pada imbalan yang diberikan. Pada Bank Syariah menggunakan pendekatan profit sharing, artinya keuntungan yang didapatkan dari pembiayaan dibagi dua, untuk biaya nasabah berdasarkan perjanjian pembagian keuntungan. Sedangkan bank konvensional menggunakan konsep biaya untuk menghitung keuntungan, artinya bunga yang dijanjikan dimuka kepada nasabah penabung merupakan ongkos yang harus dibayar oleh bank. Ketiga terletak pada sasaran kredit atau pembiayaan, pada bank syariah penyaluran pembiayaan yang akan diberikan harus memiliki kriteriakriteria syariah, disamping pertimbangan-pertimbangan keuntungan. Sedangkan di bank konvensional di salurkan kepada semua bisnis, tanpa memandang halal-haram bisnis tersebut, bahkan sering terjadi dana tersebut digunakan untuk membiayai proyek-proyek milik group perusahaan bank tersebut.

\footnotetext{
${ }^{11}$ Ibid, hlm. 156
} 
Tabungan adalah simpanan berdasarkan akad wadi'ah atau investasi dana berdasarkan akad mudharabah atau akad lain yang tidak bertentangan dengan prinsip syariah yang penarikannya hanya dapat dilakukan menurut syarat dan ketentuan tertentu yang disepakati, tetapi dapat ditarik dengan cek, bilyet giro dan atau alat lainnya yang dipersamakan dengan itu. ${ }^{12}$

Berdasarkan UU tentang Perbankan Syariah No. 21 Tahun 2008 mengenai pengertian tabungan tampak jelas bahwa tabungan terdiri dari dua jenis, yaitu tabungan wadi'ah dan tabungan mudharabah yang bermotif investasi.

Simpanan adalah dana yang dipercayakan oleh nasabah kepada bank syariah berdasarkan akad wadi'ah atau akad lain yang tidak bertentangan dengan prinsip syariah dalam bentuk giro, tabungan, atau bentuk lainnya yang dipersamakan dengan itu. Menurut UU No. 24 Tahun 2004 tentang Lembaga Penjaminan Simpanan, setiap bank wajib menjadi anggota LPS, termasuk bank syariah. LPS adalah lembaga berbadan hukum yang independen dan bertanggung jawab kepada presiden. LPS menjamin simpanan untuk setiap nasabah di satu bank. ${ }^{13}$

Sedangkan, Investasi adalah dana yang dipercayakan oleh nasabah kepada bank syariah berdasarkan akad mudharabah atau akad lain yang tidak bertentangan dengan prinsip syariah dalam bentuk deposito, tabungan, atau bentuk lainnya yang dipersamakan dengan itu.

Dalam pandangan syariah uang bukanlah merupakan suatu komoditi melainkan hanya merupakan alat untuk mencapai pertambahan nilai ekonomis (economic added value). Hal ini bertentangan dengan perbankan berbasis bunga dimana "uang mengembangbiakan

\footnotetext{
${ }^{12}$ Undang-undang Perbankan No. 10 Tahun 1998 pasal 1 ayat 9 dan Undang-undang Perbankan Syariah No. 21 Tahun 2008.

${ }^{13}$ Andri Soemitra,Bank\&Lembaga Keuangan Syariah,(Jakarta: Kencana,2009) hlm. 74
} 
Investasi Tabungan di Bank Syariah dalam Perspektif Hukum Ekonomi Syariah

uang", tidak peduli apakah uang dimana "uang mengembangbiakan uang", tidak peduli apakah uang itu dipakai dalam kegiatan produktif atau tidak. ${ }^{14}$

Tabungan dengan akad Mudharabah mempunyai nisbah bagi hasil, yang artinya nasabah mendapatkan keuntungan dari investasi sesuai dengan kesepakatan antara nasabah dan bank. Sedangkan tabungan dengan akad Wadi'ah, tidak mendapatkan bagi hasil karena tabungan wadi'ah hanya berupa titipan berbeda halnya dengan tabungan mudharabah yang merupakan investasi.

Tabungan mudharabah adalah simpanan yang penarikannya hanya dapat dilakukan menurut syarat tertentu, yang disepakati tetapi tidak dapat ditarik dengan cek atau alat yang dapat dipersamakan dengan tabungan wadiah. 15

Ketentuan tabungan mudharabah telah diatur dalam Fatwa DSN No:02/DSN-MUI/IV/2000. Dalam fatwa tersebut disebutkan ketentuan umum bagi bank mengenai tabungan mudharabah, yaitu bank betindak sebagai mudharib, sedangkan nasabah bertindak sebagai shahibul maal disini antara bank dan nasabah penyimpan, telah melakukan kesepakatan diawal akad mengenai nisbah bagi hasil. Modal harus dinyatakan dengan jumlah, dalam bentuk tunai dan bukan piutang. Dana nasabah yang disimpan dibank akan dikelola oleh bank untuk mendapatkan keuntungan, hasil pengelolaannya itulah kemudian harus dibagikan di antara bank dan nasabah, dan bank juga tidak diperkenankan mengurangi nisbah keuntungan nasabah tanpa persetujuan yang bersangkutan.

${ }^{14}$ Zainul Arifin, Dasar-Dasar Manajemen Bank Syariah, (Tanggerang: Azkia Pubhliser,2009 ) hlm. 46. 


\section{a. Tabungan Wadi'ah}

Wadi'ah dapat diartikan sebagai titipan dari satu pihak penitip (muwaddi) ke pihak penyimpan (mustawda), baik individu maupun badan hukum yang harus dijaga dan dikembalikan kapan saja muwaddi menghendakinya. Adapun yang dapat di titipkan di bank adalah suatu barang yang berharga seperti uang, dokumen, surat berharga dan barang berharga lainnya. Simpanan atau tabungan yang berakad wadiah ada dua yaitu ${ }^{16}$ :

1) Wadi'ah Yad-amanah (Trustee Depository)

Wadi'ah amanah adalah pihak yang menerima titipan tidak boleh menggunakan dan memanfaatkan uang atau barang yang dititipkan tersebut sampai diambil kembali oleh nasabah penitip. Sedangkan bank dapat meminta imbalan (ujrah) atas penitipan uang tersebut, dan memberikan bonus kepada nasabah dari hasil pemanfaatan uang titipan namun tidak boleh diperjanjikan sebelumnya dan besarnya tergantung kepada kebijakan penerima titipan (bank). Wadiah Yad-amanah memiliki karakrteristik sebagai berikut:

a) Harta atau barang yang dititipkan tidak oleh dimanfaatkan dan digunakan oleh penerima titipan.

b) Penerima titipan hanya berfungsi sebagai penerima amanah yang bertugas dan berkewajiban untuk menjaga barang yang dititipkan tanpa boleh memanfaatkannya

c) Sebagai konpensasi, penerima titipan diperkenankan untuk membebankan biaya kepada yang menitipakan.

d) Mengingat barang atau harta yang dititpkan tidak boleh dimanfaatkan oleh penerima titipan, aplikasi perbankan yang

\footnotetext{
${ }^{16}$ Ibid,,,hlm. 190-120
} 
Investasi Tabungan di Bank Syariah dalam Perspektif Hukum Ekonomi Syariah

memungkinkan untuk jenis ini adalah jasa penitipan atau save deposit box.

2) Wadi'ah Yad adh-Dhamanah (Guarantee Depository)

Wadi'ah yad adh-dhamanah adalah pihak yang menerima titipan boleh menggunakan dan memanfaatkan uang atau barang yang dititipkan. Pihak bank dalam hal ini mendapatkan hasil dari Nasabah (Muwaddi), Bank (Mustawda') pengguna dana dan bank dapat memberikan insentif kepada penitip dalam bentuk bonus. Apabila dari hasil pemanfaatan tersebut diperoleh keuntungan maka seluruhnya menjadi hak penyimpan (bank).

Wadi'ah yad-dhamanah memiliki karakteristik sebagai berikut:

a) Harta dan barang yang dititipkan boleh dan dapat dimanfaatkan oleh yang menerima titipan.

b) Barang yang dititipkan dapat menghasilkan manfaat karena dimanfaatkan. Sekalipun demikian, tidak ada keharusan bagi penerima titipan untuk memberikan hasil pemanfaatan kepada penitip.

c) Produk perbankan yang sesuai dengan akad ini yaitu tabungan dan giro.

d) Bank syari'ah tidak boleh memberikan bonus (semacam jasa giro) dalam kontrak ataupun dijanjikan dalam akad, tetepi benar-benar pemberian sepihak sebagai tanda terima kasih dari pihak bank.

e) Jumlah pemberian bonus sepenuhnya merupakan kewenangan manajemen bank syariah karena pada prinsipnya dalam akad ini penekanannya adalah titipan.

f) Produk tabungan juga dapat menggunakan akad wadiah karena pada prinsipnya tabungan mirip dengan giro, yaitu 
simpanan yang bisa diambil setiap saat. Bedanya tabungan tidak dapat ditarik dengan cek, bilyet giro atau alat lain yang dipersamakan.

Secara umum skema akad wadiah yad-dhamanah

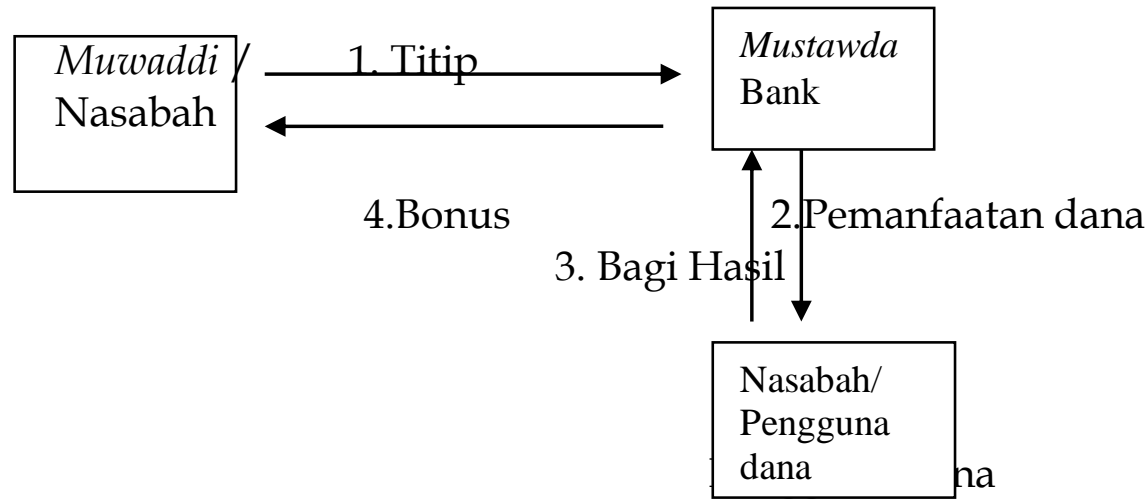

Keterangan Skema Transaksi:

1. Nasabah melakukan Akad wadi'ah yad-dhamanah

2. Bank mengelola dana yang dititipkan oleh nasabah

3. Keuntungan dari hasil usaha yang dikelola bank

4. Pemberian bonus kepada nasabah

b. Tabungan Mudharabah

Bank menghimpun dana bagi hasil atas dasar prinsip mudharabah, yaitu akad kerja sama antara pemilik dana (shahibul maal) dengan pengusaha (mudharib) untuk melakukan suatu usaha bersama, dan pemilik dana tidak boleh mencampuri pengelolaan bisnis sehari-hari. Keuntungan yang diperoleh dibagi antara keduanya dengan perbandingan (nisbah) yang telah disepakati sebelumnya. ${ }^{17}$

Prinsip mudharabah juga digunakan untuk jasa pengelolaan rekening tabungan. Salah satu syarat mudharabah adalah dananya harus dalam bentuk uang (monetary form), dalam jumlah tertentu diserahkan kepada mudharib. Oleh karena itu tabungan mudharabah

${ }^{17}$ Ibid,,,, hlm. 59 
Investasi Tabungan di Bank Syariah dalam Perspektif Hukum Ekonomi Syariah

tidak dapat ditarik sewaktu-waktu sebagaimana tabungan wadi'ah. Sehingga untuk tabungan Mudharabah biasanya tidak diberikan fasilitas ATM (Anjungan Tunai Mandiri), karena penabung tidak dapat menarik dananya dengan leluasa/dalam aplikasinya bank syariah melayani tabungan mudharabah dalam bentuk targeted saving, seperti tabungan kurban, tabungan haji dan tabungan lain yang dimaksudkan untuk suatu pencapaian target kebutuhan dalam jumlah dan atau jangka waktu tertentu.

Berdasarkan kewenangan yang diberikan oleh pihak penyimpan dana, prinsip mudharabah terbagi menjadi dua yaitu ${ }^{18}$ :

a) Mudharabah mutlaqah (URIA)

Dalam mudharabah mutlaqah atau URIA (Unrestricted Investment Account), bahwa tidak ada pembatasan bagi bankdalam menggunakan dana yang dihimpun. Nasabah tidakmemberikan persyaratan apapun kepada bank. Jadi bank memilikikebebasan penuh untuk menyalurkan dana URIA ini ke bisnismanapun yang diperkirakan menguntungkan. Mudharabah yangmemberikan kewenangan penuh kepada pihak lainnya (mudharib)dalam menentukan jenis dan tempat investasi, sedangkan keuntungan dan kerugian dibagi menurut kesepakatan bersama. Terdapat dua jenis penghimpunan dana dari penerapan mudharabah mutlaqah diatas yaitu tabungan mudharabah dan deposito mudharabah. Ketentuan dalam produk ini adalah:

b) Bank wajib memberitahukan kapada pemilik dana mengenai nisbah dan tata cara pemberitahuan keuntungan dan atau pembagian keuntungan secara resiko yang dapat ditimbulkan dari penyimpanan dana. hlm. 109

${ }^{18}$ Adiwarman Karim, Bank Islam analisi Fiqh dan Keuangan, (Jakarta: PT RajaGrafindo, 2013), 
c) Untuk tabungan mudharabah, bank dapat memberikan buku tabungan sebagai bukti penyimpanan serta kartu ATM atau alat penarikan lainnya kepada penabung. Untuk deposito mudharabah bank wajib memberikan sertifikat atau tanda penyimpanan (bilyet) deposito kepada deposan.

d) Tabungan mudharabah dapat diambil oleh penabung sesuai dengan perjanjian yang disepakati.

e) Mudharabah Muqayyadah (RIA)

Mudharabah memberikan kewenangan terbatas kepada pihak lainnya (mudhariab) dalam menentukan jenis dan tempat investasi. Sedangkan keuntungan dan kerugian dibagi menurutkesekatan bersama. Mudharabah muqayyadah (RIA) ini dibagi menjadi dua yaitu:

1) Mudharabah muqayyadah (RIA) on balance sheetMudharabah muqayyadah RIA on balance sheet yaitu simpanan khusus dimana pemilik dana dapatmenetapkan syarat-syarat tertentu yang harus dipatuhi olehbank.

2) Mudharabah muqayyadah RIA of balance SheetMudharabah muqayyadah RIA of balance Sheet merupakan penyaluran dana mudharbah langsung kepadapelaksanaan usahanya, dimana bank sebagai pihak perantara(arranger) yang mempertemukan antara pemilik dana denganpelaksana usaha

Dalam transaksi dengan prinsip mudharabah, rukun yang harus dipenuhi adalah:

1) Shahibul maal (pemilik modal/dana);

2) Mudharib (pengelola dana);

3) Amal(usaha/pekerjaan); dan

4) ljab kabul(akad). 
Investasi Tabungan di Bank Syariah dalam Perspektif Hukum Ekonomi Syariah

Jadi, pada dasarnya hanyalah tabungan wadiah yang penarikannya bisa dilakukan kapan pun, sehingga dapat diberikan ATM atau kartu sejenisnya. ${ }^{19}$

Namun dengan dikeluarkannya ketentuan BI yaitu SK Dir BI Nomor 23/63/Kep Dir tanggal 01-12-1989 dan SE Nomor 22/133/UPG tanggal 01-12-1989, dimana ketentuan tersebut ditentukan syarat-syarat penyelenggaraan tabungan, yaitu

1) Penarikan hanya dapat dilakukan dengan mendatangi bank atau ATM,

2) Penarikan tidak dapat dilakukan dengan cek, bilyet giro atau surat perintah pembayaran lain yang sejenis,

3) Bank hanya dapat menyelenggarakan tabungan dalam rupiah,

4) Ketentuan mengenai penyelenggaraan tabungan ditetapkan sendiri oleh masing-masing bank, dan

5) Bank penyelenggara tabungan diperkenankan untuk menetapkan sendiri mengenai:

a) Cara pelayanan sistem administrasi, setoran, frekuensi pengambilan, tabungan dan persyaratan lain;

b) Besarnya suku bunga, cara perhitungan, dan pembayaran bunga serta pemberian intensif, termasuk undian;

c) Nama tabungan yang diselenggarakannya.

Ketentuan inilah yang membuat banyak bank kreatif sehingga menghilangkan karakteristik tabungan yang sebenarnya. Banyak bank termasuk bank syariah, yang menetapkan tabungan dapat ditarik setiap saat, sehingga tidak dapat dibedakan antara tabungan wadi'ah dan tabungan mudharabah. 20

${ }^{19}$ Wiroso, Penghimpun Dana..., hlm. 27

${ }^{20}$ Ibid., hlm. 26. 
Ada beberapa alat penarikan tabungan, hal ini tergantung dari kebijakan masing-masing bank. Adapun alat penarikan yang dimaksud adalah ${ }^{21}$ :

a. Buku Tabungan

b. Slip Penarikan

c. Kuitansi

d. Kartu yang terbuat dari plastik (ATM)

Dalam pelaksanaannya tabungan mudharabah menunjukan adanya penggunaan akad lain dalam tabungan mudharabah, yaitu adanya akad ijarah, tetapi secara teknis penggunaannya berbeda, mudharabah yang merupakan bentuk investasi, maka akad ijarah menjadi bagian dari mudharabah tersebut. Akad ijarah digunakan sebagai penyewaan fasilitas yang diberikan oleh bank, yang beban administrasinya ditanggung oleh nasabah itu sendiri, misalnya nasabah yang sudah membuka rekening tabungan akan diberikan fasilitas kartu ATM, yang nantinya kartu tersebut dipergunakan untuk memenuhi kebutuhan keuangan nasabah, dan bahkan bisa digunakan pada ATM (Plus, Prima, dan Bersama), maka dalam hal ini pihak bank boleh membebankan biaya administrasi kepada nasabah. Tetapi mengenai penerapannya tetap berdasarkan ketentuan dari bank, karena bank mempunyai kewenangan dalam menentukan pelaksanaannya.

Secara umum, skema tabungan akad mudharabah dapat digambarkan sebagai berikut:

${ }^{21}$ Djoni S. Gozali, Rachmadi Usman, Hukum Perbankan, (Jakarta: Sinar Grafika, 2012), hlm. 


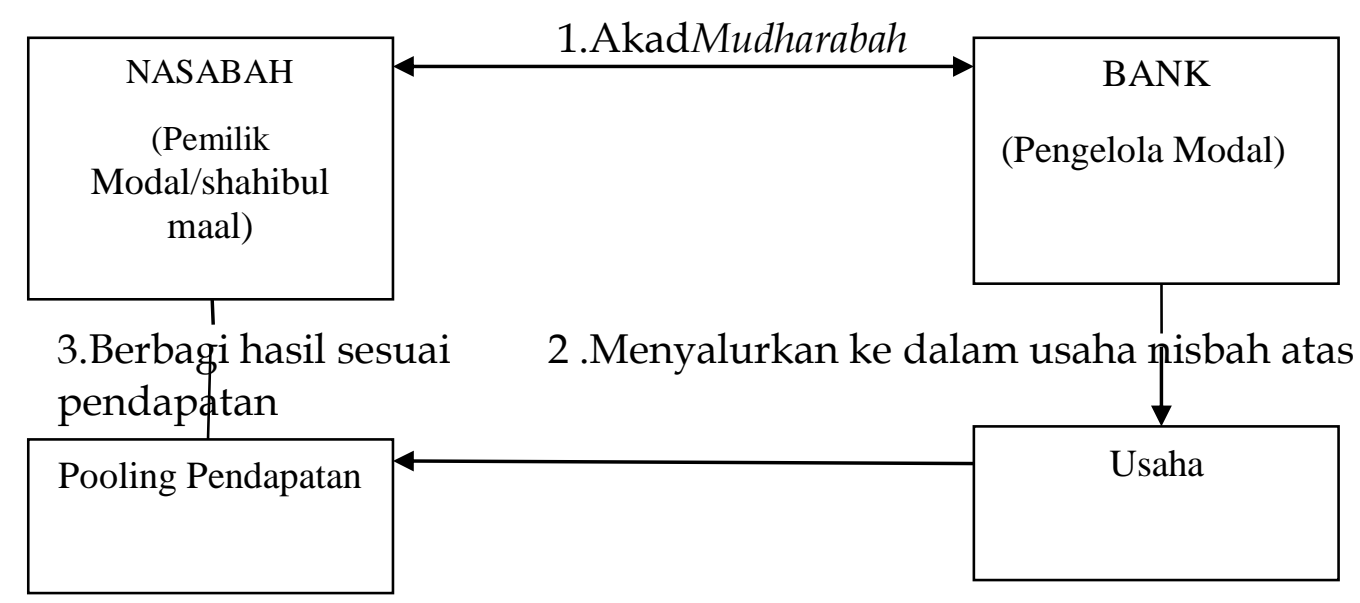

Keterangan Skema Transaksi:

1. Nasabah melakukan Akad Mudharabah dan melakukan kesepakatan pembagian keuntungan yang dinyatakan dalam nisbah.

2. Bank menggunakan dana nasabah untuk membiayai usaha.

3. Keuntungan dari hasil usaha dibagi sesuai kesepakatan nisbah nasabah dan bank.

Secara umum, skema Akad Ijarah untuk fasilitas elektronik dan layanan dapat digambarkan sebagai berikut ${ }^{22}$,

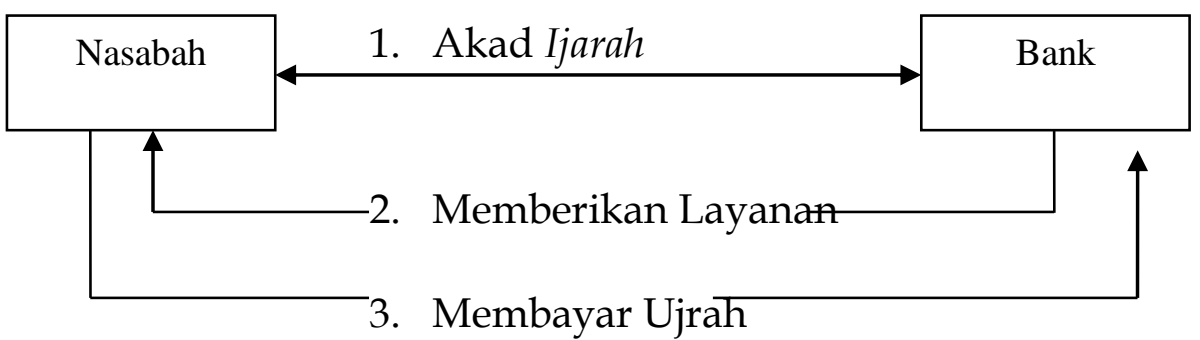

Keterangan skema:

1. Nasabah melakukan akad ijarah dengan bank terkait tabungan

2. Bank memberikan layanan elektronik kepada nasabah

3. Nasabah membayar ujrah dalam bentuk biaya administrasi atas layanan elektronik yang diberikan bank.

\footnotetext{
${ }^{22}$ Buku Panduan Akad Produk Bank Muamalat Indonesia.
} 


\section{Asas Hukum Investasi}

Undang-undang Nomor 25 Tahun 2007 Pasal 3 ayat (1) menentukan 10 asas dalam melaksanakan penanaman modal atau investasi, sebagai berikut 23 :

a. Asas Kepastian hukum, yaitu asas dalam negara hukum yang meletakan hukum dan ketentuan peraturan perundang-undangan sebagai dasar dalam setiap kebijakan dan tindakan dalam bidang penanaman modal atau investasi.

b. Asas Keterbukaan, yaitu asas yang terbuka terhadap hak masyarakat untuk memperoleh informasi yang benar, jujur, dan tidak diskriminatif tentang kegiatan penanaman modal atau investasi dalam segala bentuknya.

c. Asas Akuntabilitas, yaitu asa yang menentukan bahwa setiap kegiatan dan hasil akhir dari penyelenggaraan penanaman modal dipertangungjawabkan kepada masyarakat atau rakyat.

d. Asas perlakuan yang sama dan tidak membedakan-bedakan asal negara, adalah asas perlakuan pelayanan nondiskriminasi berdasarkan ketentuan perundang-undangan, baik antara penanaman modal dalam negeri, dan penanaman modal dari satu negara asing, dann penanam modal dari negara asing lainnya.

e. Asas Kebersamaan, adalah asas yang mendorong peran seluruh penanam modal untuk secara bersama-sama dalam kegiatan usahausaha untuk mewujudkan kesejahteraan rakyat.

f. Asas Efisiensi Berkeadilan, adalah asas yang mendasari pelaksanaan penanaman modal atau investasi dengan mengedepankan efisiensi berkeadilan dalam usaha mewujudkan iklim usaha yang adil, kondusif, dan berdaya saing.

${ }^{23}$ Abdul Manan,Hukum Ekonomi Syariah:Dalam Prespektif Kewenangan Peradilan Agama, (Jakarta: Kencana, 2012), hlm. 159-161. 
Investasi Tabungan di Bank Syariah dalam Perspektif Hukum Ekonomi Syariah

g. Asas Berkelanjutan, adalah asas yang secara terencana mengupayakan berjalannya proses pembangunan melalui penanaman modal untuk menjamin kesejahteraan dan kemajuan dalamsegala aspek kehidupan, baik untuk masa kini maupun yang akan datang.

h. Asas Berwawasan Lingkungan, adalah asas penanaman modal atau investasi yang dilakukan dengan tetap memerhatikan dan mengutamakan perlindungan dan pemeliharaan lingkungan hidup.

i. Asas Kemandirian, adalah asas penanaman modal atau investasi yang dilakukan dengan tetap mengedepankan potensi bangsa dan negara tidak menutup diri pada masuknya modal asing demi terwujudnya pertumbuhan ekonomi

j. Asas Keseimbangan Kemajuan dan Kesatuan Ekonomi Nasional, adalah asas yang berupaya menjaga keseimbangan kemajuan ekonomi wilayah dalam kesatuan ekonomi nasional.

\section{Tabungan dalam Prespekif Hukum Ekonomi Syariah}

Berdasarkan penelusuran pustaka yang dilakukan oleh penulis maka, adapun yang menjadi landasan dan kekuatan hukum dalam menginvestasikan harta melalui tabungan di bank syariah dalam prespektif Hukum Ekonomi Syariah adalah:

a. Landasan Syariah Tabungan ${ }^{24}$

Q.S. An-Nisa : 29

"Hai orang-orang yang beriman, janganlah kamu saling memakan (mengambil) harta sesamamu dengan jalan yang batil, kecuali dengan jalan perniagaan yang Berlaku dengan suka sama-suka di antara kamu."

${ }^{24}$ Wiroso, Pengimpunan Dana ..., hlm. 47. 
"Hai orang-orang yang beriman, bertakwalah kepada Allah dan hendaklah Setiap diri memperhatikan apa yang telah diperbuatnya untuk hari esok (akhirat); dan bertakwalah kepada Allah, Sesungguhnya Allah Maha mengetahui apa yang kamu kerjakan."

Dari ayat di atas bisa di pahami bahwa Allah menganjurkan untuk mencari harta dan mengembangkan harta dengan cara berniaga atau berinvestasi.

Kegiatan usaha penghimpunan dana, penyalurandana dan pelayanan jasa bank berdasarkan PrinsipSyariah yang dilakukan oleh bank merupakan jasaperbankan. Dalam melaksanakan jasa perbankandimaksud bank wajib memenuhi Prinsip Syariah.Pemenuhan Prinsip Syariah dimaksud dilaksanakandengan memenuhi ketentuan pokok hukum Islamantara lain prinsip keadilan dan keseimbangan('adl wa tawazun). Kemaslahatan (maslahah), universalisme (alamiyah) serta tidak mengandunggharar, maysir, riba, zalim dan objek haram.

b. Hadits

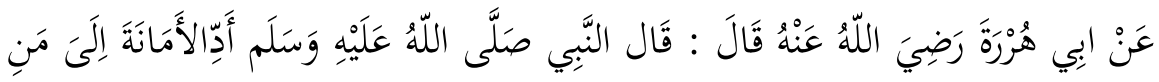

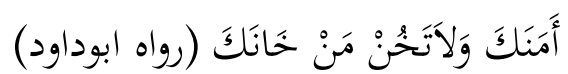

"Dari Abu Hurairoh berkata: 'Bersabda Rasulullah saw: sampaikanlah (tunaikanlah) amanat kepada yang berhak menerimanya dan jangan membalas khianat kepada orang yang telah mengkhianatimu." (HR. Abu Dawud). ${ }^{25}$

c. Kaidah Fiqh Tabungan wadi'ah dan mudharabah ${ }^{26}$

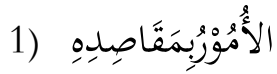

"Segala sesuatu tergantung tujuannya."

${ }^{25}$ Syarif Hidayatullah, Qawa'id Fiqhiyyah dan Penerapan dalam Transaksi Keuangan Syariah Kontemporer, (Jakarta: Gramata Publishing, 2012), hlm. 100

${ }^{26} \mathrm{Ibid},$, ,hlm. 114. 


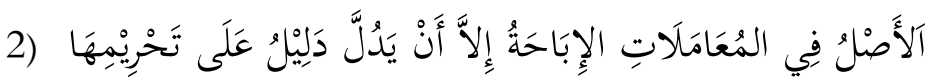

"Pada dasarnya semua bentuk muamalah itu boleh dilaksanakan, kecuali ada dalil yang mengharamkannya."

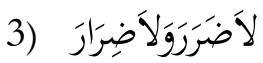

"Tidak boleh membahayakan dan tidak boleh pula membahayakan orang lain."

4) العُرْمُ بِالْغُنْمِ

"Kerugian dengan keuntungan (ditanggung dan dibagi bersama)."

d. Undang-undang No. 21 Tahun $2008^{27}$

Tabungan adalah simpanan berdasarkan akad wadi'ah atau investasi dana berdasarkan akad mudharabah atau akad lain yang tidak bertentangan dengan prinsip syariah yang penarikannya hanya dapat dilakukan menurut syarat dan ketentuan tertentu yang disepakati, tetapi dapat ditarik dengan cek, bilyet giro dan atau alat lainnya yang dipersamakan dengan itu.

Berdasarkan UU tentang Perbankan Syariah No. 21 Tahun 2008 mengenai pengertian tabungan tampak jelas bahwa tabungan terdiri dari dua jenis, yaitu tabungan wadi'ah dan tabungan mudharabah yang bermotif investasi.

e. Ketentuan BI SK Dir BI Nomor 22/63/Kep Dir tanggal 01-12-1989 dan SE BI Nomor 22/133/UPG 28 :

1) Penarikan hanya dapat dilakukan dengan mendatangi bank atau ATM,

2) Penarikan tidak dapat dilakukan dengan cek, bilyet giro atau surat perintah pembayaran lain yang sejenis,

3) Bank hanya dapat menyelenggarakan tabungan dalam rupiah, 
4) Ketentuan mengenai penyelenggaraan tabungan ditetapkan sendiri oleh masing-masing bank, dan

5) Bank penyelenggara tabungan diperkenankan untuk menetapkan sendiri mengenai:

a) Cara pelayanan sistem administrasi, setoran, frekuensi pengambilan, tabungan dan persyaratan lain;

b) Besarnya suku bunga, cara perhitungan, dan pembayaran bunga serta pemberian intensif, termasuk undian;

c) Nama tabungan yang diselenggarakannya.

Sesuai dengan ketentuan BI Dalam aplikasinya, tabungan wadi'ah dan mudharabah sama-sama diberikan fasilitas ATM untuk mempermudah akses nasabah dalam bertransaksi di bank syariah

\section{f. $\mathrm{KHES}^{29}$}

Dalam KHES, pada bab VII pasal 187-188 disebutkan bahwa rukun dan syarat mudharabah, sebagai berikut:

1) Rukun

a) Shahibul maal (pemilik modal)

b) Mudharib (pelaku usaha)

c) Akad

2) Syarat

a) Pemilik modal wajib menyerahkan dana dan atau barang yang berharga kepada pihak lain untuk melakukan kerjasama dalam usaha.

b) Penerima modal menjalankan usaha dalam bidang yang disepakati

\footnotetext{
${ }^{29}$ Kompilasi Hukum Ekonomi Syariah, 2008
} 
Investasi Tabungan di Bank Syariah dalam Perspektif Hukum Ekonomi Syariah

c) Kesepakatan bidang usaha yang dilakukan diterapkan dalam akad

Dan pada bab XIV pasal 370 -373 disebutkan bahwa rukun dan syarat wadi'ah, sebagai berikut:

1) Rukun

a) Muwaddi' (Penitip)

b) Mustauda' (Penerima titipan)

c) Akad

2) Syarat

a) Akad dapat dinyatakan dengan lisan, tulisan, atau isyarat

b) Harta wadi'ah harus dapat dikuasai dan diserahterimakan

c) Muwaddi dan mustauda dapat membatalkan akad wadi'ah sesuai kesepakatan.

g. Fatwa Tentang Tabungan No. 02/DSN-MUI/IV/200030

Pertama : Tabungan ada dua jenis yaitu

1) Tabungan yang tidak dibenarkan secara syari'ah, yaitu tabungan yang berdasarkan perhitungan bunga.

2) Tabungan yang dibenarkan, yaitu tabungan yang berdasarkan prinsip Mudharabah dan Wadi'ah.

Kedua : Ketentuan Umum Tabungan berdasarkan

Mudharabah:

1) Dalam transaksi ini nasabah bertindak sebagai shahibul mal atau pemilik dana, dan bank bertindak sebagai mudharib atau pengelola dana.

2) Dalam kapasitasnya sebagai mudharib, bank dapat melakukan berbagai macam usaha yang tidak bertentangan dengan prinsip

\footnotetext{
${ }^{30}$ Fatwa Tentang Tabungan No. 02/DSN-MUI/IV/2000
} 
syari'ah dan mengembangkannya, termasuk di dalamnya mudharabah dengan pihak lain.

3) Modal harus dinyatakan dengan jumlahnya, dalam bentuk tunai dan bukan piutang.

4) Pembagian keuntungan harus dinyatakan dalam bentuk nisbah dan dituangkan dalam akad pembukaan rekening.

5) Bank sebagai mudharib menutup biaya operasional tabungan dengan menggunakan nisbah keuntungan yang menjadi haknya.

6) Bank tidak diperkenankan mengurangi nisbah keuntungan nasabah tanpa persetujuan yang bersangkutan.

Ketiga : Ketentuan Umum Tabungan berdasarkan Wadi'ah yaitu

1) Bersifat simpanan.

2) Simpanan bisa diambil kapan saja (on call) atau berdasar-kan kesepakatan.

3) Tidak ada imbalan yang disyaratkan, kecuali dalam bentuk pemberian ('athaya) yang bersifat sukarela dari pihak bank.

Fatwa dewan syariah nasional menjelaskan bahwa tabungan yang dibenarkan secara syariah yakni tabungan yang tidak menggunakan sistem bunga yaitu wadi'ah dan mudharabah. tabungan wadi'ah yakni sebagai titipan murni dari satu pihak ke pihak yang lain, baik individu maupun badan hukum, yang harus dijaga dan dikembalikan kapan saja si penitip menghendakinya. Sedangkan mudhrabah yaitu bentuk kerja sama antara dua atau lebih pihak di mana pemilik modal (shahibul mal) mempercayakan sejumlah modal kepada pengelola (mudharib) dengan suatu perjanjian di awal.

Bank diperbolehkan memanfaatkan dana dari nasabah untuk menjalankan suatu usaha yang tidak bertentangan dengan syariah, dan 
Investasi Tabungan di Bank Syariah dalam Perspektif Hukum Ekonomi Syariah

bank diperbolehkan melakukan mudharabah dengan pihak lain dengan syarat akad mudharabah menggunakan akad mudharabah muthlaqah. Beda halnya dengan mudharabah muqayyadah yakni bank tidak diperkenankan menggunakan dana nasabah untuk berbagai usaha atas kehendak bank, karena pemilik dana berhak menentukan syarat dan pembatasan kepada pengelola dalam penggunaan dana tersebut dengan jangka waktu, tempat, jenis usaha. Dalam akad mudharabah ini jumlah dana yang akan disetor pada bank tidak dalam bentuk piutang yakni tunai. Pembagian keuntungan antara nasabah dengan bank harus dituangkan dalam bentuk nisbah/presentase dalam akad pembukaan rekening.

Dalam prakteknya tabungan di Bank Syariah lebih banyak menggunakan akad wadiah Yad adh-dhamanah dan Mudharabah Muthlaqoh, karena dengan menggunakan kedua akad tersebut Bank bisa lebih leluasa untuk mengelola dan menyalurkan dana yang didapatkan ke sektor-sektor usaha yang halal.

\section{Penutup}

Investasi di bank syariah melalui produk tabungan bisa menjadi alternatif bagi para investor yang tidak ingin menanggung resiko yang begitu besar. Adapun keuntungannya berinvestasi dengan tabungan di bank syariah adalah dana yang di investasikan investor bisa diambil kapan saja. Dan dana yang di investasikan oleh investor juga akan di kelola ke sektor usaha yang jauh dari unsur gharar. Investasi melalui tabungan juga tidak perlu khawatir akan dana yang diinvestasikan raib atau hilang karna simpanan atau tabungan di jamin oleh lembaga penjamin simpanan (LPS).

Regulasi tabungan di bank syariah diatur oleh Undang-undang No. 21 Tahun 2008, dan Fatwa DSN No:02/DSN-MUI/IV/2000. Hukum dari berinvestasi di Bank Syariah adalah boleh, karena dengan berinvestasi di bank 
syariah secara perlahan kita dapat membantu pemerataan ekonomi dan kesejahteraan ekonomi (mendatangkan mashlahah).

\section{Daftar Pustaka}

Ahmad., Kamaruddin, 2004, Dasar-Dasar Manajemen Investasi Dan Portofolio,Jakarta : Rineka Cipta

Antonio ., Muhammad Syafi'I, 2001, Bank Syariah Dari Teori ke Praktik, Jakarta: Gema Insani.

Arifin., Zainul,2009, Dasar-Dasar Manajemen Bank Syariah,Tanggerang: Azkia Pubhliser,2009

Ascarya, 2008, Akad E Produk Bank Syariah, Jakarta: PT RajaGafindo Persada

Gozali , Djoni S., Rachmadi Usman, 2012, Hukum Perbankan, Jakarta: Sinar Grafika.

Hidayatullah.,Syarif,2012, Qawa'id Fighiyyah dan Penerapan dalam Transaksi Keuangan Syariah Kontemporer, Jakarta: Gramata Publishing

Huda., Nurul dan Mustafa Edwin Nasution, 2008, Investasi pada Pasar Modal Syariah, Jakarta: Kencana.

Karim., Adiwarman A, 2013, Bank Islam Analisis Fiqih dan Keuangan, Jakarta: PT RajaGafindo Persada.

Manan., Abdul, 2012, Hukum Ekonomi Syariah:Dalam Prespektif Kewenangan Peradilan Agama, Jakarta: Kencana

Muhammad, 2005, Manajemen Bank Syariah,Yogyakarta: UPP AMP YKPN.

Nafik., Muhammad HR, 2009,Bursa Efek dan Investasi Syariah,Jakarta:Serambi.

Panduan Akad Produk Bank Muamalat Indonesia

Wirdyaning, et al.,2005,Bank dan Asuransi Islam di Indonesia, cet ke-1,Jakarta: Kencana.

Wiroso, 2005 Penghimpun Dana dan Distribusi Hasil Usaha Bank Syariah, Jakarta:Grasindo.

Soemitra, Andri, 2009, BankELembaga Keuangan Syariah,Jakarta: Kencana.

Sudarsono, Heri, 2003, Bank dan lembaga Keuangan Syariah Deskripsi dan Ilustrasi, Yogyakarta: Ekonisia.

Fatwa DSN No:02/DSN-MUI/IV/2000.

KHES

Undang-undang Perbankan Syariah No. 21 Tahun 2008

Undang-undang No. 25 Tahun 2007 Tentang Penanaman Modal

Undang-undang Perbankan No. 10 Tahun 1998

SK Dir BI Nomor 22/63/Kep Dir dan SE BI Nomor 22/133/UPG 